\title{
Analyzing Trends in Water Table Elevations at the Marcell Experimental Forest, Minnesota, U.S.A.
}

\author{
Anna Stockstad ${ }^{*}$, Ella Gray, ${ }^{a}$ Stephen Sebestyen ${ }^{b}$, Nina Lany ${ }^{c}$, Randall Kolkea ${ }^{b}$, \& Marcella Windmuller-Campione \\ ${ }^{a}$ Department of Forest Resources, University of Minnesota- Twin Cities, St. Paul, Minnesota \\ ${ }^{b} U S D$ A Forest Service Northern Research Station, Grand Rapids, Minnesota \\ 'USD A Forest Service Northern Research Station, Durbam, New Hampshire
}

https:// doi.org/10.33697/ajur.2020.032

Student: stock.523@umn.edu*

Mentor:mwind@umn.edu

\begin{abstract}
Water table fluctuations in peatlands are closely coupled with the local climate setting and drive critical ecosystem processes such as nutrient cycling. In Minnesota, USA, peatlands cover ten percent of the surface area, approximately 2.5 million hectares, some of which are actively managed for forest products. To explore the relationship between peatland water tables and precipitation, long-term data (1961 to 2019) were used from the Marcell Experimental Forest in northern Minnesota. Starting in 1961, water table data from seven peatlands, including two types of peatlands (bogs and fens), were measured. We used the Theil-Sen estimator to test for monotonic trends in mean monthly water table elevations for individual peatlands and monthly precipitation. Water levels in bogs were both more variable and had mean water table elevations that were closer to the surface. Individual trends of water table elevations differed among peatlands. Water table elevations increased over time in three of the bogs studied and decreased over time in two of the bogs studied. Trends within fens were notably nonlinear across time. No significant linear trend was found for mean monthly precipitation between 1961 and 2019. These results highlight differences in peatlands types, local physiography, and the importance of understanding how changes in long-term dynamics coupled with changing current conditions will influence the effects of water table fluctuations on ecosystem services. The variability of water table elevations in bogs poses potential difficulties in modeling these ecosystems or creating adaptive management plans.
\end{abstract}

\section{KEYWORDS}

Peatlands; Hydrology; Water tables; Bogs; Fens; Monitoring; Minnesota; Climate Change

\section{INTRODUCTION}

Worldwide northern (boreal and subarctic) peatlands have stored carbon (estimated at $500 \mathrm{Pg}$ of carbon) due to slow decomposition rates. ${ }^{1-3}$ Theoretically, aboveground ecosystem productivity increases as a function of belowground carbon. ${ }^{4-6}$ In peatlands, however, aboveground productivity presents as extremely low growth rates due to infertile conditions, regardless of the surplus of belowground carbon. ${ }^{4-7}$ Northern peatland carbon stores were historically considered "stable" or "inactive". In response to a changing climate, however, hydrological and biogeochemical feedbacks have revealed the extreme sensitivity of peatland carbon stocks to fluctuations in decomposition rates., 2

Water table dynamics in peatlands control biogeochemical cycles in these systems and are closely linked with local and global climate. ${ }^{1}$ Understanding the feedback processes between water tables and climate in peatlands is critical in predicting the future dynamics of these ecosystems. Subsequently, the magnitude of ecosystem services provided by peatlands, such as carbon storage and biodiversity, are influenced by these feedback processes. ${ }^{2}$ Carbon cycling within peatlands is linked with fluctuations of the water table since decomposition rates are controlled by soil moisture content. ${ }^{1-3,8}$ Slight changes in peatland hydrology can cause significant feedbacks in local carbon dynamics and productivity, and thus have major implications for the global carbon cycle. $8,9,10,11$

Long-term changes in water tables may lead to changes in forest composition, notably shifts in understory species, which has major implications for forest management. ${ }^{12,13,14}$ Local hydrology strongly influences the composition of plant communities as well as the growth of vegetation. For example, some species, especially the evergreen plants of the heath family Ericaceae, are 
adapted to survive in growth-limiting conditions such as acidic and low fertility soils. If these growing conditions were to change, the species composition would likely shift as well. ${ }^{13}$ Temperature and hydrology are key drivers of change in forest composition and productivity, as demonstrated by McPartland et al. ${ }^{14}$ Decreases in shrub cover were seen in the drought-only experiments (i.e. water table drawdown), while drought treatments with warming were correlated with an increase in shrub cover. ${ }^{12}$ In contrast, the relationship between water tables and tree species in peatlands, specifically black spruce (Picea mariana), is less clear. A study within bogs at the MEF analyzed the long-term correlation (1963 to 2010) of black spruce growth to several climatic factors, and found a weak relationship between annual tree growth and water table elevation. ${ }^{12}$ These various growth strategies suggest a possible decoupling of evapotranspiration and water table elevation due to the perched root systems of black spruce located in Sphagnum hummocks above high water tables. ${ }^{2}$ In addition, rooting depth may increase with declines in water table elevation, which would likely shift vegetation community structure. ${ }^{15}$ Thus, multiple feedback responses due to changes in climatic conditions, including changes in water table elevation, may determine the transition of peatland plant communities. These relationships suggest that the long-term management of peatlands, and specifically black spruce, will become increasingly complex under a changing climate. Fluctuations in water tables may cause a cascading effect on forest composition and local hydrology, which may influence forest productivity and health on an ecosystem scale. Therefore, forest managers must consider the several feedbacks between local hydrology, forest composition, and structure in order to adaptively manage these systems.

Differences in peatland hydrology strongly influence feedback responses. Hydrological characteristics, vegetation, and chemistry are used to classify peatland type (i.e. bog or fen). Both bogs and fens have organic soils. Bogs are perched above local aquifers and only receive precipitation inputs. Bog soils are acidic and low in plant available nutrients. By contrast, fens intersect local aquifers and receive groundwater inputs in addition to precipitation. ${ }^{4}$ Soils and water in fens are less acidic than in bogs (i.e. poor fens) and may even be neutral to alkaline (i.e. rich fen). 4,8 , Water tables in bogs are typically more variable than in fens since these systems do not receive water inputs from local aquifers and only receive precipitation inputs. ${ }^{1,2,4,9}$ Water table elevation is inversely correlated to decomposition rates. A lowering of the water table will generally result in increased decomposition rates. ${ }^{9}$ The concentration of dissolved minerals is also generally higher in fens compared to bogs. ${ }^{3,4}$ Consequently, the dynamics of peatland hydrology and biogeochemical processes are tightly linked and can influence forest composition and subsequently have major implications for forest management. ${ }^{12,13,14}$

The timing, intensity, and frequency of precipitation, runoff, and ET influence the hydrology of peatlands, and these processes are not stationary as climate changes. To explore trends, long-term monitoring is required. The Marcell Experimental Forest (MEF), located in northern Minnesota, USA, includes a long-term monitoring station of both bogs and fens. Specifically, peatland water table and meteorological monitoring have been ongoing since $1961 .{ }^{4}$ Therefore, the MEF provides records of peatland water table elevations in both bogs and fens which can be utilized to quantify trends and differences in annual and decadal patterns in types of peatlands.

Given the complexity and interacting feedbacks within peatlands systems, long-term data are required to identify trends in hydrological patterns. The Marcell Experimental Forest (MEF) research program, located in northern Minnesota, USA, includes monitoring of peatland water table and meteorological data since $1961 .{ }^{4}$ Therefore, these records of peatland water table elevations in both bogs and fens which can be utilized to quantify trends and differences in annual and decadal patterns in types of peatlands. Using MEF data, we evaluated trends in water table elevations in bogs and fens at the MEF, the relationship of those trends to precipitation, and the magnitude of peatland responses to climate. We hypothesized that water tables within bogs would be more variable than that of fens due to the reduced influence of local aquifers in bogs than in fens. Secondly, we hypothesized that precipitation would demonstrate a significant linear trend during the period of record. Our results can aid natural resource managers in the development adaptive management plans that consider the site-specific responses of these stands to climate.

\section{METHODS AND PROCEDURES}

\section{Study region}

Northern Minnesota, USA, represents the southern edge of the boreal forest. ${ }^{11}$ The composition of Minnesota's boreal forests includes a mix of upland conifer species, wet hardwood forests, and conifer peatland forests. ${ }^{16,17}$ Minnesota's conifer peatland forests are dominated by three species, tamarack (Larix laricina), black spruce, and northern white cedar (Thuja occidentalis), and represent approximately 450,000 hectares, 550,000 hectares, and 245,000 hectares of forest land, respectively. All three species are managed for commercial timber production; black spruce is the second most harvested pulpwood species after aspen (Populus spp.), representing millions of dollars in direct and indirect revenue within Minnesota. ${ }^{18}$ 
Study site 4

The 1114-hectare MEF is located forty kilometers north of Grand Rapids, Minnesota, USA. Formally established as a longterm monitoring site in 1962 to study peatland ecology and hydrology, the site is funded and operated by the USDA Forest Service.

The MEF contains both fens and bogs, as well as upland terrestrial ecosystems. Both forested and open peatlands exist within the MEF. Vegetation in fens may include tamarack, black spruce, willow (Salix spp.), speckled alder (Alnus incana ssp. rugosa), sedges (Carex spp.), and other species. Several species of Ericaceae are found in bogs. Black spruce and eastern tamarack are the major overstory trees in forested bogs. ${ }^{4}$ Due to nutrient limitation in bogs, overstory trees have low productivity and slow growth. ${ }^{11}$ Sphagnum mosses are the predominant understory species within bogs and fens.

Climate at the MEF is defined as sub-humid continental with an average annual temperature of $3 \mathrm{C}$ and average annual precipitation of $78.0 \mathrm{~cm}$ ( \pm 1 standard deviation of $11.0 \mathrm{~cm} ; 75 \%$ of which occurs during snow-free periods). Average January temperature is $-1{ }^{\circ} \mathrm{C}$ and average July temperature is $19^{\circ} \mathrm{C} .4$ Typical of northern latitudes, large diurnal and seasonal fluctuations in temperature occur.

The MEF is divided into six research watersheds, each having a central peatland and surrounding upland. These six research watersheds have been extensively researched with additional information on each watershed, instrumentation, and research methods summarized by Sebestyen et. al. ${ }^{4}$

We investigated the water table elevations of the S1, S2, S3, S4, S5, and S6 peatlands. We also analyzed a research site (not a watershed) called Bog Lake Peatland. The bogs are located within the S1, S2, S4, S5, and S6 watersheds. The S3 watershed contains a rich fen and Bog Lake Peatland is a poor fen. Soil classification is similar across peatlands at the MEF (Table 1). Typic borohemists contain wood fragments, intermediately decomposed (hemic), and are reddish in color. ${ }^{4}$ Typic borosaprists are composed of a surface layer of Sphagnum moss and ericaceous shrubs, with partially and fully decomposed organic layers below (saprist). ${ }^{4}$ Soil water chemistry, specifically $\mathrm{pH}$, differs between the two peatland types, with bogs being more acidic than fens (Table 1).

\begin{tabular}{|c|c|c|c|c|c|}
\hline Watershed & $\begin{array}{c}\text { Starting } \\
\text { date of } \\
\text { record } \\
\text { (Year-month) }\end{array}$ & $\begin{array}{c}\text { Size } \\
\text { (hectares) }\end{array}$ & Soil series & Description & $\begin{array}{c}\text { Soil water } \\
\mathrm{pH}\end{array}$ \\
\hline S1 bog & 1961-01 & 8.1 & Greenwood & Typic Borohemist & $3.9 \pm 0.2$ \\
\hline S2 bog & 1961-01 & 3.2 & Loxley & Typic Borosaprist & $3.9 \pm 0.2$ \\
\hline S3 fen & 1961-04 & 18.6 & Moose Lake; Lupton & $\begin{array}{l}\text { Typic Borosaprist; } \\
\text { Typic Borohemist }\end{array}$ & $6.9 \pm 0.1$ \\
\hline S4 bog & 1962-04 & 8.1 & Greenwood & Typic Borohemist & $4.1 \pm 0.3$ \\
\hline S5 bog & $1962-03$ & 6.1 & Moose Lake; Lupton & $\begin{array}{l}\text { Typic Borosaprist; } \\
\text { Typic Borohemist }\end{array}$ & 4.1 \\
\hline S6 bog & 1965-01 & 2.0 & Seelville peat & Typic Borosaprist & 4.9 \\
\hline $\begin{array}{c}\text { Bog Lake } \\
\text { Peatland (fen) }\end{array}$ & $1990-07$ & NA & Greenwood & Typic Borohemist & 4.1 \\
\hline
\end{tabular}

Table 1. Description of peatland soil classification and chemistry at the Marcell Experimental Forest. ${ }^{4}$

Trees in the S1 bog and S3 fen at the MEF were experimentally harvested several decades ago. Black spruce were strip cut from the S1 bog in 1969, and the remaining strips were then removed in 1974. The S3 fen was clearcut and slash was burned during the winter of 1972 to 1973 . The other peatlands have not been experimentally manipulated and are reference sites.

\section{Statistical analysis}

Monthly mean water table elevation ( $\mathrm{mWTE}$ ) was calculated by averaging the daily maximum water table elevation dataset for each month during the period of record. ${ }^{19,20}$ To standardize across the different elevations of the peatlands in the landscape, monthly mean water table elevations were mean-centered by subtracting the overall mean water table elevation during the full period of record from $\mathrm{mWTE}$ for each peatland. The selected time range for all data was 1961 (oldest available data) to 2019 
(most recent available data). The starting date of record differed slightly for individual peatlands based on when observational studies were first established (Table 1) Peatland water table elevations at the MEF were monitored using float-driven well levels, with a precision of $\pm 0.3 \mathrm{~cm}$. Additional details on the data collection instrumentation and methods were summarized by Sebestyen et al. ${ }^{4}$ Each watershed dataset contained one peatland type.

Long-term trends in water table elevations in individual peatlands were initially visualized in RStudio v. $1.1 .463 .{ }^{21} \mathrm{For}$ each individual peatland, a time series plot of $\mathrm{mWTE}$ with regression line, autocorrelation function, decomposition function of the time series, and monthly box plot were created. Coefficients of variation were calculated for each peatland.

Precipitation (1961-2019) was measured in forest clearings at the S2 and S5 watersheds. ${ }^{19,} 20$ Precipitation data at the MEF was measured to the closest $0.03 \mathrm{~cm}$. To match the frequency of the water table data, monthly precipitation data was aggregated from daily precipitation values. Trends in monthly precipitation were tested using nonparametric regression with the Theil-Sen estimator in the "openair" package. ${ }^{22,23}$ Total, seasonal, and de-seasoned regressions were calculated for each precipitation record. Seasonal data was divided into spring (March, April, May), summer (June, July, August), autumn (September, October, November), and winter (December, January, February). A statistical test was considered significantly different when a p-value was less than 0.05 .

The direction and significance of trends in water table elevation were also analyzed using the Theil-Sen estimator in the "openair" package. ${ }^{22,23}$ Total, seasonal, and de-seasoned regressions were tested for each peatland. ${ }^{22,23}$ Mean-centered water table elevation was used in the regression to standardize across absolute elevations. De-seasoned regressions were conducted as a part of the Theil-Sen function in the "openair" package in order to identify irregular patterns in mean-centered water table elevation. Trends in fens were non-monotonic and thus were excluded from the analysis. A time series plot was used to visualize trends in mWTE in the S3 fen and Bog Lake Peatland. Separate time series plots over the 1990 to 2019 period were used to compare the bogs to the two fens, as limited by the shorter record from the Bog Lake Peatland.

\section{RESULTS}

Trends in water table elevation for individual peatlands

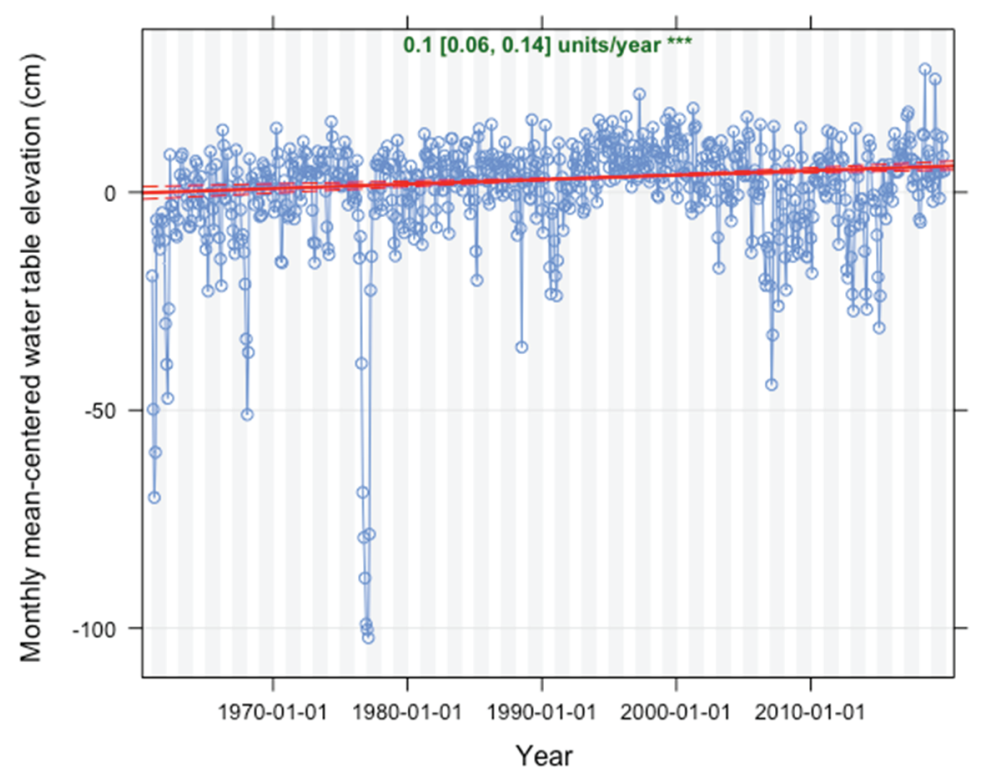

Figure 1a. Changes in monthly mean-centered water table elevation for the $\mathrm{S} 1 \mathrm{bog}$. The linear trend was statistically significant ( $\mathrm{p}<0.001)$. The values at the top of the figure denote the slope of the line (cm/year) and the $95 \%$ confidence interval $(\mathrm{cm})$.

Figure 1 shows the change in monthly mean-centered water table for each bog through the period of record. Slopes of trend lines (cm/year) and 95\% confidence intervals $(\mathrm{cm})$ are included for each bog. Trends in mean-centered WTE and mWTE varied across peatlands (Figure 1, 2). Peatlands that are in close spatial proximity on the landscape exhibited different trends in $\mathrm{mWTE}$. Trends within peatland type (bog versus fen) were not consistent. There was a net decrease in mWTE in the Bog Lake Peatland, while the S3 fen had a net increase over the full period of record. It is important to note that the period of study began in 1990 for the Bog Lake Peatland, and in 1961 for the S3 fen (Table 1). The trend in the S3 fen, when reevaluated over 
the same period from 1990 to 2019 was similar to the trend for Bog Lake Peatland. When viewed over the same time period (Figure 3), the bogs demonstrated trends which are visually different from the trends in the fens. For each peatland, the autocorrelation function, decomposition function, and monthly boxplots were used mainly as exploratory analyses of the data, and thus will not be discussed here.

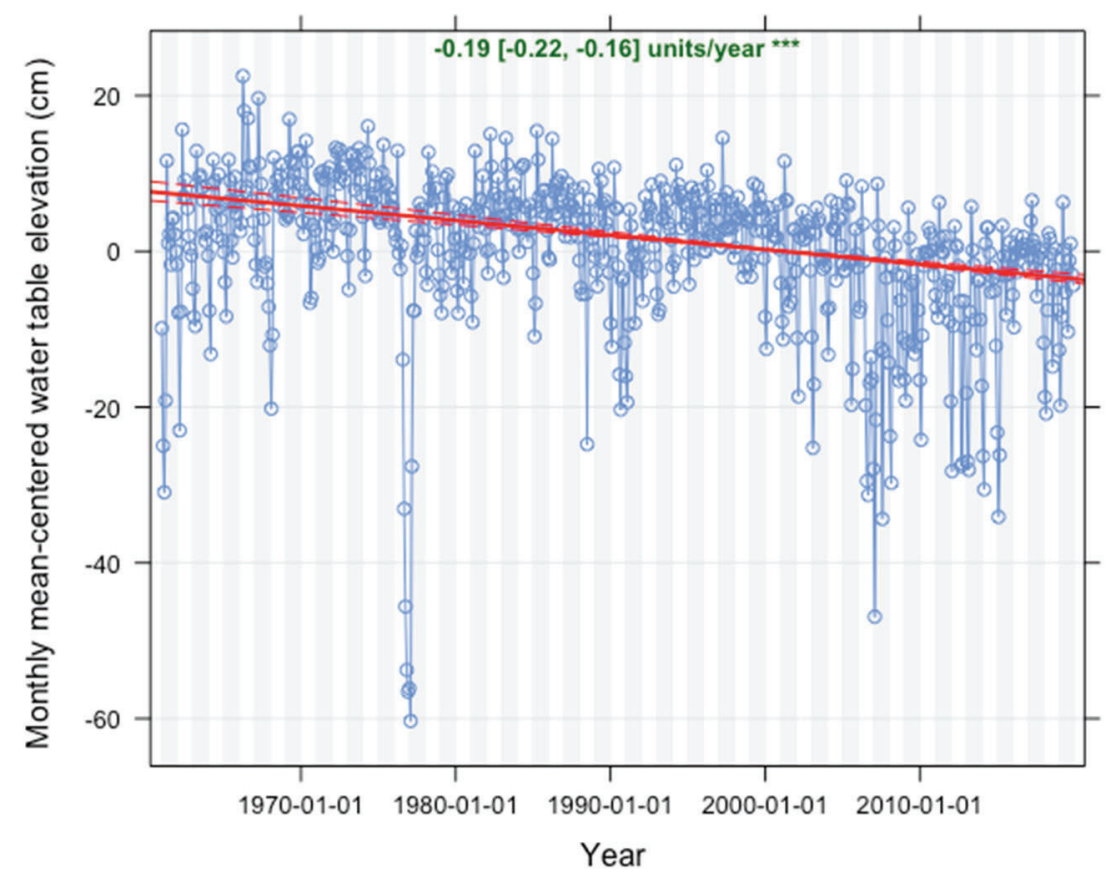

Figure 1b. Changes in monthly mean-centered water table elevation for the S2 bog. The linear trend was statistically significant $(\mathrm{p}<0.001)$. The values at the top of the figure denote the slope of the line $(\mathrm{cm} /$ year) and the $95 \%$ confidence interval $(\mathrm{cm})$.

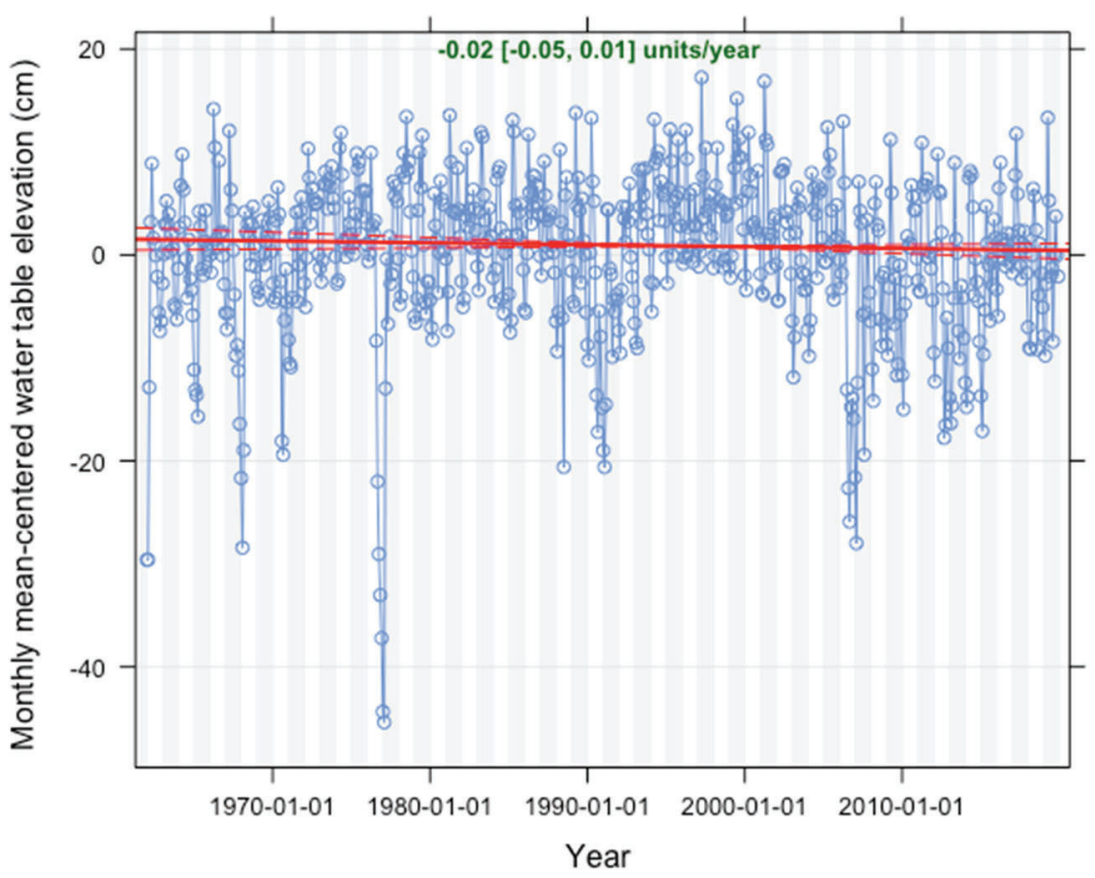

Figure 1c. Changes in monthly mean-centered water table elevation for the $\$ 4$ bog. The linear trend was not statistically significant $(p>0.05)$. The values at the top of the figure denote the slope of the line $(\mathrm{cm} /$ year) and the $95 \%$ confidence interval $(\mathrm{cm})$. 


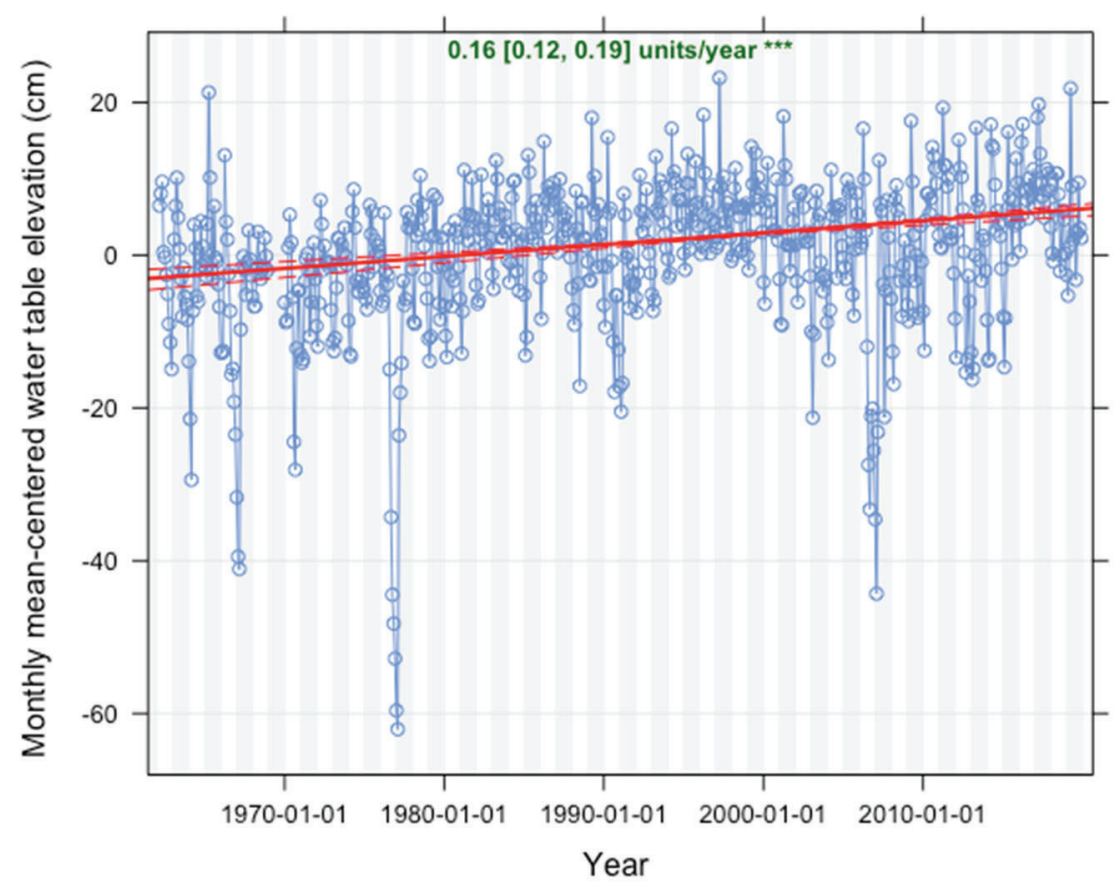

Figure 1d. Changes in monthly mean-centered water table elevation for the S5 bog. The linear trend was statistically significant ( $\mathrm{p}<0.001)$. The values at the top of the figure denote the slope of the line (cm/year) and the $95 \%$ confidence interval $(\mathrm{cm})$.

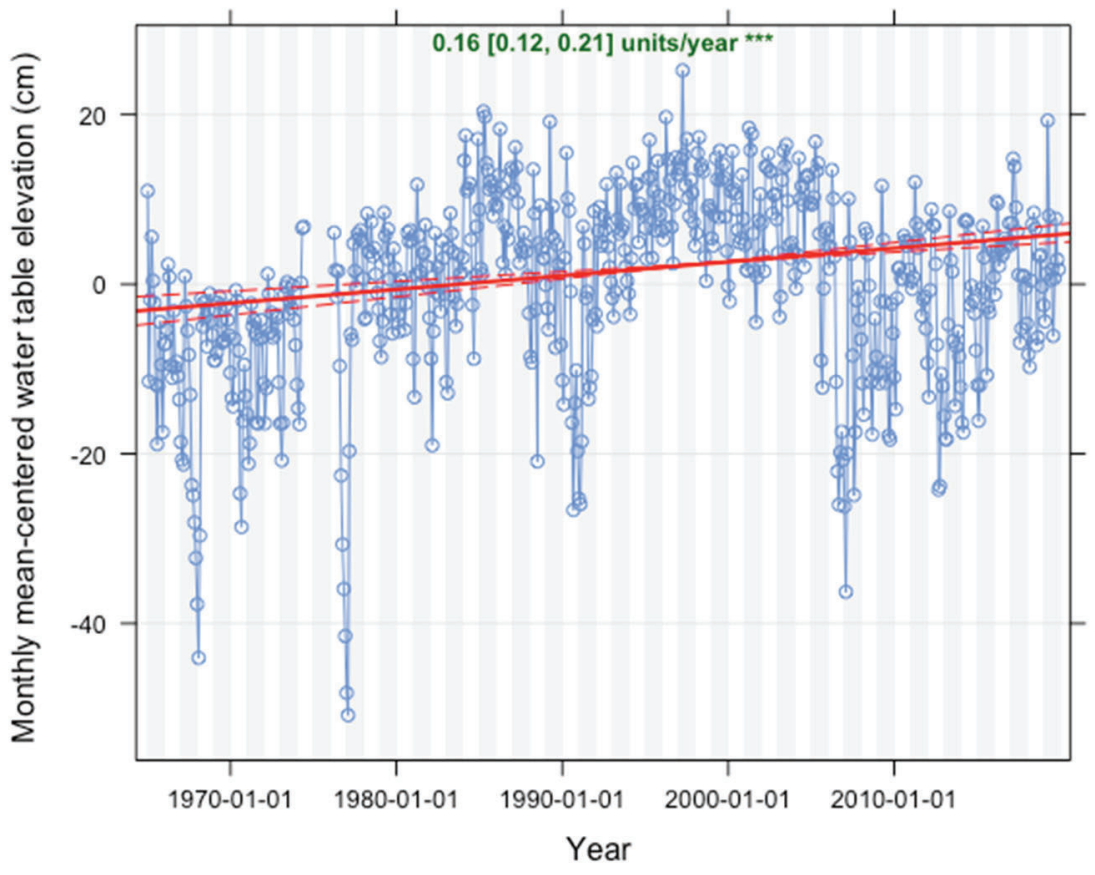

Figure 1e. Changes in monthly mean-centered water table elevation for the S6 bog. The linear trend was statistically significant ( $\mathrm{p}<0.001)$. The values at the top of the figure denote the slope of the line $(\mathrm{cm} /$ year) and the $95 \%$ confidence interval $(\mathrm{cm})$. 


\section{Changes in mWTE in S3 fen}

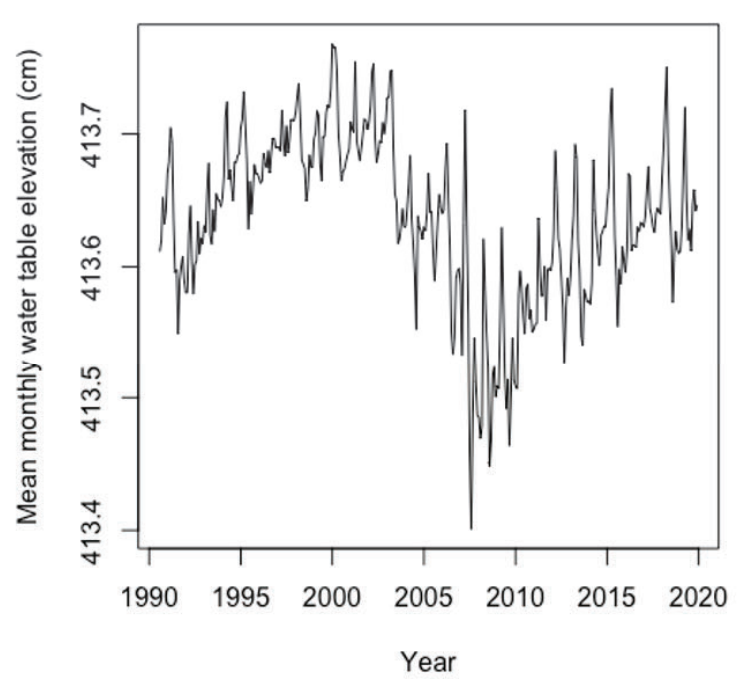

Changes in mWTE in Bog Lake fen

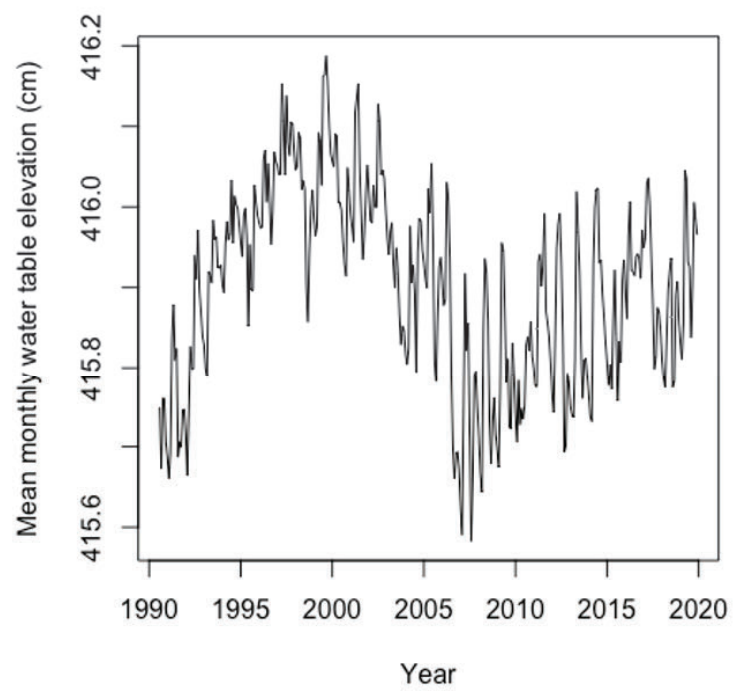

Figure 2. Trends in mean monthly water table elevation (mWTE) in the S3 fen and Bog Lake Peatland. Fens were excluded from nonparametric analyses due to data being non-monotonic.

Variability in monthly water table elevations

The Bog Lake Peatland had a higher coefficient of variation than all other peatlands except for the S1 bog (Table 2). The variability of the S3 fen was lower than the bogs.

\begin{tabular}{|c|c|c|c|}
\hline \multicolumn{2}{|c|}{ 1961-2019 } & \multicolumn{2}{c|}{ 1990-2019 } \\
\hline \hline Peatland & $\begin{array}{c}\text { Coefficient of } \\
\text { variation }\end{array}$ & Peatland & $\begin{array}{c}\text { Coefficient of } \\
\text { variation }\end{array}$ \\
\hline S1 bog & 0.00034 & S1 bog & 0.00024 \\
\hline S2 bog & 0.00024 & S2 bog & 0.00022 \\
\hline S3 fen & 0.00016 & S3 fen & 0.00015 \\
\hline S4 bog & 0.00018 & S4 bog & 0.00018 \\
\hline S5 bog & 0.00024 & S5 bog & 0.00021 \\
\hline S6 bog & 0.00026 & S6 bog & 0.00024 \\
\hline $\begin{array}{c}\text { Bog Lake } \\
\text { Peatland }\end{array}$ & 0.00029 & $\begin{array}{c}\text { Bog Lake } \\
\text { Peatland }\end{array}$ & 0.00029 \\
\hline
\end{tabular}

Table 2. Coefficients of variation (standard deviation divided by mean) for each peatland over the full period of record, as well as the 1990-2019 period. A higher coefficient of variation denotes higher variability. 

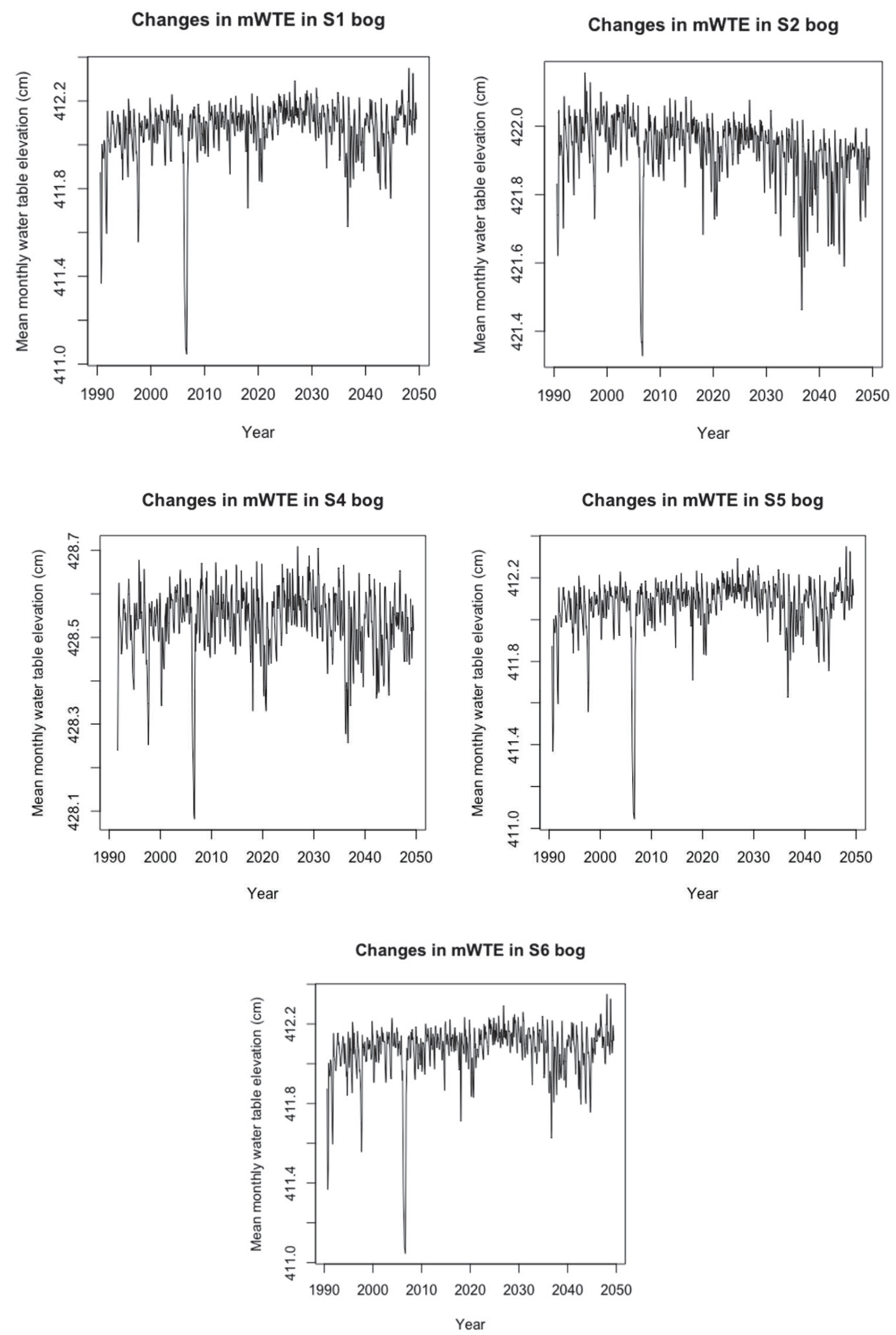

Figure 3. Trends in mean monthly water table elevation (mWTE) in the bogs over the same time period (1990-2019) as the fens. 
Nonparametric regression with Theil-Sen estimator

Linear trends in monthly mean-centered WTE were significant for all except the S4 bog (Figure 1; Table 3). Fens were excluded from nonparametric analysis after initial exploratory analyses showed that trends were not monotonic, which violates a key assumption of the Theil-Sen estimator. The Theil-Sen estimator was applied to monthly mean-centered WTE to standardize across the landscape; thus, the Theil-Sen figures demonstrate deviations from the mean of all monthly water table observations during the period of record for each peatland. (Figure 1).

\begin{tabular}{|c|c|c|c|c|c|}
\hline & Spring & Summer & Autumn & Winter & Deseasoned \\
\hline \multicolumn{6}{|l|}{ S1 Bog } \\
\hline Slope & 0.13 & 0.10 & 0.10 & 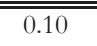 & 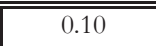 \\
\hline Intercept & 5.0 & 1.7 & 1.8 & 3.8 & 0.63 \\
\hline Significance & *** & *** & ** & * & *** \\
\hline \multicolumn{6}{|l|}{ S2 Bog } \\
\hline Slope & -0.17 & -0.19 & -0.20 & -0.21 & -0.20 \\
\hline Intercept & 7.7 & 6.9 & 7.7 & 1.8 & 6.0 \\
\hline Significance & $* * *$ & $* * *$ & $* * *$ & $* * *$ & $* * *$ \\
\hline \multicolumn{6}{|l|}{ S4 Bog } \\
\hline Slope & 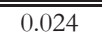 & -0.015 & -0.033 & -0.047 & $\begin{array}{l}-0.024 \\
\end{array}$ \\
\hline Intercept & 4.4 & 2.6 & 2.2 & -2.5 & 1.42 \\
\hline Significance & 0.42 & 0.42 & 0.14 & 0.083 & $*$ \\
\hline \multicolumn{6}{|l|}{ S5 Bog } \\
\hline Slope & "0.20 & 0.15 & "0.14 & "0.13 & "0.157 \\
\hline Intercept & 1.8 & -0.23 & -0.82 & -6.5 & -2.3 \\
\hline Significance & *** & $* * *$ & $* * *$ & *** & $* * *$ \\
\hline \multicolumn{6}{|l|}{ S6 Bog } \\
\hline Slope & 0.20 & 0.17 & 0.12 & 0.16 & 0.16 \\
\hline Intercept & 1.3 & -1.6 & -1.7 & -7.3 & -2.3 \\
\hline Significance & *** & *** & * & ** & *** \\
\hline
\end{tabular}

Table 3. Slopes, intercepts, and significance levels of Theil-Sen estimator for all bogs. Fens were notably non-monotonic and were not included in the TheilSen analysis. Slopes are in units of centimeters per year. Intercepts are in units of centimeters. Significance levels are denoted as $\mathrm{p}<0.001=* * *, \mathrm{p}<0.01=$

Precipitation trends

$$
* *, \mathrm{p}<0.05=* .
$$

We found no linear increases or decreases over time in monthly precipitation at the S5 or S2 stations between 1961 and 2019

(Figure 4). 


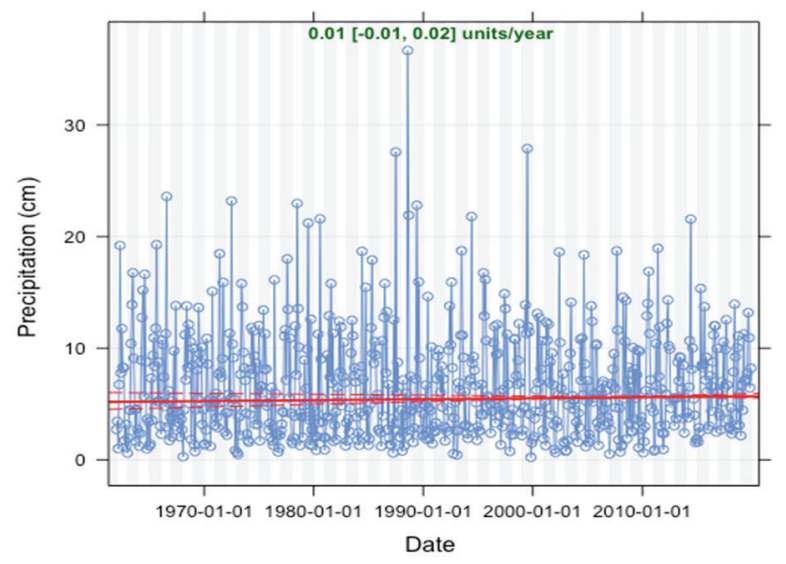

Figure 4a. Linear trends in monthly precipitation for the S5 meteorological station was not significant $(\mathrm{p}>0.05)$. Values above each figure denote slope $(\mathrm{cm})$ and $95 \%$ confidence intervals $(\mathrm{cm})$.

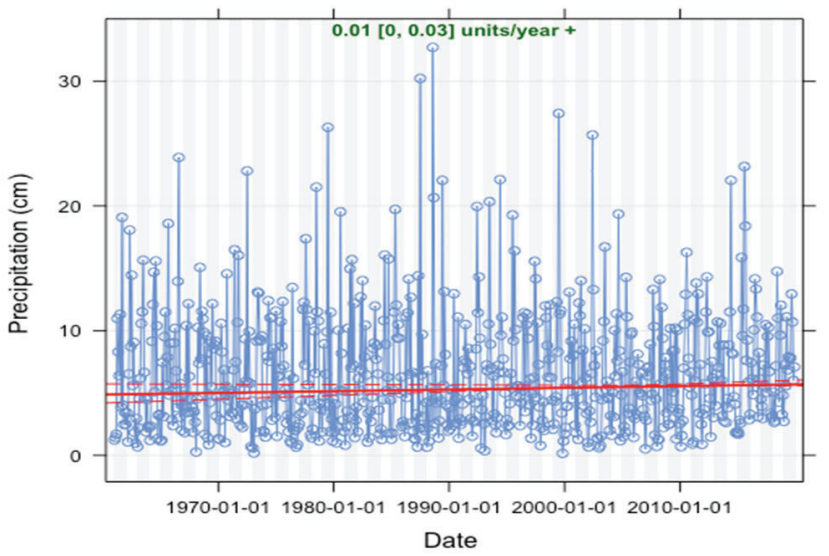

Figure 4b. Linear trends in monthly precipitation for the S2 meteorological station was not significant $(\mathrm{p}>0.05)$. Values above each figure denote slope $(\mathrm{cm})$ and $95 \%$ confidence intervals $(\mathrm{cm})$.

\section{DISCUSSION}

Our results demonstrate the variability and diversity of water table elevation during similar climate conditions in peatlands, as well as the non-linearity of peatland responses to monthly precipitation in northern Minnesota peatlands. The magnitude of change in water table elevations differed among individual watersheds and were not consistent within peatland type. However, these trends were significantly different through time in general.

The responsiveness of water tables in bogs versus fens is an intrinsic hydrologic characteristic of these ecosystems. Fens are connected to local aquifers and groundwater inflow, while bogs are perched above aquifers and only receive precipitation inputs. ${ }^{1}$, 2, 4, 9 However, the Bog Lake Fen had the highest coefficient of variation than all peatlands except for the S1 bog, which contradicts our initial hypothesis (Figure 1, 2, 3; Table 2). The lack of connection to local aquifers in bogs should increase the magnitude of water table responses to precipitation fluctuations, but this prediction is not clear from this analysis alone. The bogs contain more outliers than the fens, and trends in the fens appear to be more cyclical. The two peatland types are different, but the variability between bogs and fens did not support our initial hypothesis that bogs would be more variable than fens. The differences between the two fens, due to the harvesting of the S3 fen, may have resulted in the lack of clear differences in variability between the two peatland types. Ideally, both fens would receive the same experimental treatments to allow for the direct comparison to bogs; however, the difference between these two fens complicates the direct comparison to the bogs.

The analysis of individual peatlands revealed unique and inconsistent water table trends both within and between peatland types. For example, the mW'TE did not significantly change in the S4 bog, in contrast to either a positive or negative trend in other watersheds (Figure 1, 3). When seasonality was removed, trends within all peatlands were significant except for the S4 bog, although the trends were not all the same direction (Table 3). The water table may be influenced by internal feedbacks, such as fluctuations in ET from vegetation. ${ }^{24}$ External forcings, such as the harvesting activities performed in the S1 bog and S3 fen, also play a major role in the response of peatland water tables. ${ }^{25}$ Therefore, the long-term trends of mWTE are site-specific and nonlinear. ${ }^{24,}, 26$

Long-term water table dynamics were also not consistent within a peatland type, and bogs were more variable than the fens. When the two fens are viewed from 1990 on, the trend within the S3 fen mirrors that of the Bog Lake Peatland (Figure 2). The Bog Lake Peatland is mainly vegetated with Sphagnum moss and sedges, as well as some stunted tamarack. This peatland is a poor fen with a mean pH of 4.1 (1992-2019), and also lacks a surface water outlet (Table 1). On the other hand, the S3 rich fen is vegetated with willow, speckled alder, black spruce, tamarack, and paper birch. The entire fen was clearcut and the harvesting slash burned in the winter of 1972 to 1973.4 No water table response to the harvesting was observed. ${ }^{25}$ The S3 fen, with a $\mathrm{pH}$ of $6.9 \pm 0.1$, is also less acidic than the Bog Lake Peatland and also has a surface water outlet (Table 1). ${ }^{4}$ Even with differences in vegetation, chemistry, and land management practices over the 1961 to 2019 period, water table responses were similar in both fens from 1990 to 2019. The connection of fens to surrounding aquifers acts as a stabilizing factor in long-term water table elevations. ${ }^{4}$ Large-scale commercial harvesting, even when conducted in the winter, has the potential to change the bulk density and hydraulic conductivity of the underlying peat through compression of the organic soil and removal of tree roots, which subsequently affects soil structure. ${ }^{9}$ However, these results show that water tables in both fens did not demonstrate a significant response to harvesting activities. The hydrological properties (i.e. connection to aquifer) of fens may allow for some magnitude of 
resilience to change following large-scale harvesting operations. Semi-cyclical mWTE fluctuations occurred in both fens. These trends may represent the stabilization of water tables via connection to local aquifers, which provide a consistent input of water. ${ }^{27}$

Water table elevations were inconsistent within the two peatland types and our analyses demonstrated no clear similarities to precipitation trends (Table 2). The S1, S5, and S6 bogs experienced net increases in mWTE, and S2 and S4 experienced net decreases in mWTE (Figure 2). The trend in S4 mean-centered WTE, however, was only significant when the seasonal component was removed, and the slope coefficient was an order of magnitude smaller than the other peatlands (Table 3). Each bog had unique water table fluctuations through time, even though there was no significant linear trend in precipitation (Figure 1, 4). For example, the $\mathrm{S} 2$ bog had a significant negative slope in mW'TE when seasonality was considered, showing that the water table has significantly fallen since 1961 (Table 2). The five bogs are similar in composition; the canopies consist mainly of black spruce and tamarack, and the understories are dominated by Ericaceous plants and Sphagnum moss. The net decrease in mWTE in the S2 bog may suggest that ET has potentially increased since 1961 since vegetation is similar across the bogs, but previous studies have found that variations in peatland water tables may not control ET. ${ }^{28}$ It is critical to note that this analysis of precipitation only examined linear trends and did not consider factors such as snowmelt and inter-annual variability. Further detailed analysis of changes in the form of precipitation, inter- and intra-annual variability, and timing of precipitation is required to make further conclusions about the relationship between water tables and precipitation.

Regardless, the long-term relationship between mWTE and precipitation in the bogs is inconsistent among the sites. The variability of water table elevations in bogs poses potential difficulties in modeling these ecosystems or creating adaptive management plans. The bogs analyzed in this study were similar in composition, history, and location but each had unique a response despite the fact that all peatlands experienced the same amount of precipitation. This suggests that the responses of bogs to precipitation over long time-scales are extremely site-specific and difficult to predict., 3, 6, 12 Understanding the diversity of peatland water table responses to warming air temperature and increasing ET through analysis of historical datasets is essential to representing peatlands in Earth Systems Models, which in turn, provide projections of future conditions. Regardless, in the context of management, this complexity of peatlands water table responses, especially differences between bogs and fens, suggests the need for site-specific knowledge, instead of generalized regional models.

Water table dynamics in peatlands are also complicated by microtopography, which is characterized by hummocks and hollows. These fine-scale variations lead to spatially complex water table dynamics that can be difficult to parameterize. ${ }^{29-31} \mathrm{Changes}$ in water table levels may lead to altered fine-root growth, which is strongly influenced by decreased water table elevations. ${ }^{32}$ Black spruce and tamarack are both shallow-rooted species. Accordingly, longer durations of lowered water tables may increase drought stress of the overstory trees. These feedbacks would subsequently change rates of ET. Understanding these dynamics is especially crucial in the context of peatland carbon dynamics, since water tables and carbon cycling are closely coupled. Not only do fens and bogs possibly respond differently to precipitation and disturbances (e.g. harvesting activities), but individual bogs demonstrated different trends in mWTE between 1961 and 2019. It is important to note, however, that differences in drainage area, trees (size, age, and basal area), and elevation above surrounding aquifers may have caused these differences.

Changes in water table elevation may also alter potential greenhouse gas (GHG) emissions from peatlands. ${ }^{10,27,33}$ For example, water table drawdowns can lead to increased tree growth and carbon dioxide emissions due to enhanced decomposition. On the other hand, high water tables promote methanogenesis and methane emissions from peatland soils. ${ }^{10,}{ }^{29}$ While carbon cycle responses at the Marcell Experimental Forest are beyond the scope of this study, this study identifies uncertainties related to potential ecosystem-level responses in peatlands to changes in water table elevation.

The nearly sixty-year temporal span of these data provides preliminary insights on the long-term precipitation patterns in northern Minnesota. The IPCC Fifth Assessment Report predicts that precipitation will increase in the long term in northern latitudes. ${ }^{34}$ In addition, peatlands are expected to be extremely responsive to an increasing global temperature, which may lead to increased ET and decreased mWTE. ${ }^{29,33,34}$ The unique responses among fens and bogs in northern Minnesota represent the need for additional research and monitoring in these systems. The highly localized responses among fens and bogs have implications for carbon cycle models, which may be over or underestimating outputs depending on ecosystem representation (or lack thereof) and model parameters. ${ }^{35,36}$ Additionally, these highly localized responses have implications for modeling or predicting future forest composition and structure. The development of regional or state-wide forest management plans may be unable to fully account for the many possible peatland water table responses under a changing climate and continue to highlight the importance of evaluating individual sites and stands when considering forest management activities in peatland forest ecosystems.

While the simple linear modeling presented in this research serves as a foundational first step in this study, further consideration of these data could include: 1) making direct comparisons between monthly precipitation and water table data; 2) using the precipitation data to parse periods of time so that the authors can determine whether sites are behaving similarly to one another 
during different climatic conditions. Across all of these approaches, the authors should attempt to analyze for significant differences between bogs and fens as well as disturbed and undisturbed sites.

\section{CONCLUSIONS}

This study demonstrated the complexity of peatland hydrological dynamics and the uncertainties of the long-term relationship between mWTE and precipitation. ${ }^{37}$ Water table elevations differed between seasons both within and between peatlands, and bogs were more variable than fens (Table 3). In addition, bogs and fens had significantly different trends in mWTE (Figure 1, 2, 3). The non-linearity of water table responses to rainfall variability is likely due to complex physical and biophysical flowpaths and feedbacks. Precipitation serves as only one control on mWTE, in addition to temperature fluctuations, ET, and other processes. Therefore, these results represent a small portion of the complex responses of peatlands over time. However, the results of this study revealed site-specific responses of each peatland to changes in moisture and the inconsistency of trends within the same peatland type. This site specificity has implications for the representation of peatlands in models. The management history, geomorphic setting, subsurface heterogeneity, connectivity to surrounding uplands, and composition of each peatland likely all influence the response of a site to changes in precipitation, which can result in uncertainty of how water tables will respond with air warming, increasing ET, and other manifestations of climate change. ${ }^{37,38,39}$

Given our current limited understanding of forest ecosystem successional development pathways of peatland forests in Minnesota, there is still much to learn. This learning process becomes more complicated as climate change continues to influence ecosystem processes in peatlands. This complexity is demonstrated by our results which show inconsistent results between fens and bogs and also the variable response among the different bogs. This research highlights the need for natural resource managers to utilize an adaptive management framework, which relies on continual assessment and monitoring. Data from management at the southern edge of the boreal forest will provide critical information as these changes move further north. Adaptive forest management would allow for flexible decision-making that accounts for the site-specific behavior of peatland ecosystems. The complexity of peatland responses to climate requires the need for ecologically-sound management decisions in these systems, as well as a detailed understanding of local hydrodynamics and the sensitivity of the landscape to change.

\section{ACKNOWLEDGEMENTS}

The authors thank the staff at the Marcell Experimental Forest for the collection and compilation of the precipitation and water table data.

\section{REFERENCES}

1. Macrae, M. L., Devito, K. J., Strack, M., \& Waddington, J. M. (2013) Effect of water table drawdown on peatland nutrient dynamics: Implications for climate change. Biogeochemistry, 112(1), 661-676. https:// doi.org/ 10.1007/s10533-012-9730-3

2. Ise, T., Dunn, A., Wofsy, S., Moorcraft, P. (2008) High sensitivity of peat decomposition to climate change through watertable feedback. Nature Geosci 1, 763-766. https:// doi.org/10.1038/ngeo331

3. Strack, M., Waddington, J. M., \& Tuittila, E.-S. (2004) Effect of water table drawdown on northern peatland methane dynamics: Implications for climate change. Global Biogeochemical Cycles, 18(4). https:// doi.org/10.1029/2003GB002209

4. Sebestyen, S. D., Dorrance, C., Olson, D. M., Verry, E. S., Kolka, R. K., Elling, A. E., \& Kyllander, R. (2011) Long-term monitoring sites and trends at the Marcell Experimental Forest. In Kolka, R. K., Sebestyen, S. D., Verry, E. S., \& Brooks, K. N. (Eds.), Peatland biogeochemistry and watershed bydrology at the Marcell Experimental Forest (pp. 15-71). Boca Raton, FL: CRC Press.

5. Babst, F., Bouriaud, O., Papale, D., Gielen, B., Janssens, I. A., Nikinmaa, E., Ibrom, A., Wu, J., Bernhofer, C., Köstner, B., Grünwald, T., Seufert, G., Ciais, P., \& Frank, D. (2014) Above-ground woody carbon sequestration measured from tree rings is coherent with net ecosystem productivity at five eddy-covariance sites. New Phytologist, 201(4), 1289-1303.

https:// doi.org/10.1111/ nph.12589

6. Grant, R. F. (2004) Modeling topographic effects on net ecosystem productivity of boreal black spruce forests. Tree Physiology, 24(1), 1-18. https://doi.org/10.1093/treephys/24.1.1

7. Laiho, R., \& Prescott, C. E. (1999) The contribution of coarse woody debris to carbon, nitrogen, and phosphorus cycles in three Rocky Mountain coniferous forests. Canadian Journal of Forest Research, 29(10), 1592-1603. https:/ / doi.org/10.1139/ x99-132

8. Strack, M., Waddington, J. M., Bourbonniere, R. A., Buckton, E. L., Shaw, K., Whittington, P., \& Price, J. S. (2008) Effect of water table drawdown on peatland dissolved organic carbon export and dynamics. Hydrological Processes, 22(17), $3373-3385$. https:/ / doi.org/10.1002/ byp.6931

9. Whittington, P. N., \& Price, J. S. (2006) The effects of water table draw-down (as a surrogate for climate change) on the hydrology of a fen peatland, Canada. Hydrological Processes, 20(17), 3589-3600. https:/ / doi.org/ 10.1002/ hyp.6376

10. Koven, C. D., Ringeval, B., Friedlingstein, P., Ciais, P., Cadule, P., Khvorostyanov, D., Krinner, G., \& Tarnocai, C. (2011) Permafrost carbon-climate feedbacks accelerate global warming. Proceedings of the National Academy of Sciences, 108(36), 1476914774. https:// doi.org/10.1073/pnas.1103910108 
11. Cleland, D.T., Avers, P.E., McNab, W.H., Jensen, M.E., Bailey, R.G., King, T., Russell, W.E. (1997) National Hierarchical Framework of Ecological Units. Published in, Boyce, M. S.; Haney, A., ed. 1997. Ecosystem Management Applications for Sustainable Forest and Wildlife Resources. Yale University Press, New Haven, CT. pp. 181-200.

12. Dymond, S. F., D’Amato, A. W., Kolka, R. K., Bolstad, P. V., Sebestyen, S. D., Gill, K., \& Curzon, M. T. (2019) Climatic controls on peatland black spruce growth in relation to water table variation and precipitation. Ecohydrology, $12(7)$, e2137. bttps://doi.org/10.1002/eco.2137

13. Bisbee, K. E., Gower, S. T., Norman, J. M., \& Nordheim, E. V. (2001) Environmental controls on ground cover species composition and productivity in a boreal black spruce forest. Oecologia, 129(2), 261-270. https://doi.org/10.1007/s004420100719

14. McPartland, M. Y., Kane, E. S., Falkowski, M. J., Kolka, R., Turetsky, M. R., Palik, B., \& Montgomery, R. A. (2019) The response of boreal peatland community composition and NDVI to hydrologic change, warming and elevated carbon dioxide. Global Change Biology. https:// doi.org/10.1111/gcb.14465

15. Iversen, C. M., Childs, J., Norby, R. J., Ontl, T. A., Kolka, R. K., Brice, D. J., McFarlane, K. J., \& Hanson, P. J. (2017) Fineroot growth in a forested bog is seasonally dynamic, but shallowly distributed in nutrient-poor peat, Plant and Soil, 1-21. https://doi.org/10.1007/s11104-017-3231-z.

16. Aaseng, N., Almendinger, J., Rusterholz, K., Wovcha, D., Klein, T.R., (2003) Field guide to the native plant communities of Minnesota: the Laurentian Mixed Forest Province. Minnesota Department of Natural Resources, Saint Paul, Minnesota.

17. Johnston, W.F., (1977) Manager's handbook for black spruce in the north-central states. Gen. Tech. Rep. NC-34 18.

18. Hillard, S., Bergstrand, K. Deckard, D. Minnesota's Forest resources (2017) Department of Natural resources; Division of Forestry, 92pp.

19. Sebestyen, S.D., E.S. Verry, A.E. Elling, R.L. Kyllander, D.T. Roman, J.M. Burdick, N.K. Lany, and R.K. Kolka. (2020) Marcell Experimental Forest daily precipitation, 1961 - ongoing ver 1. Environmental Data Initiative. https:/ / doi.org/10.6073/pasta/75646a3bd41ba3219d0e578e8374eef7

20. Sebestyen, S.D., E.S. Verry, A.E. Elling, R.L. Kyllander, D.T. Roman, J.M. Burdick, N.K. Lany, and R.K. Kolka. (2020) Marcell Experimental Forest daily peatland water table elevation, 1961 - ongoing ver 1. Environmental Data Initiative. bttps:/ / doi.org/10.6073/pasta/6e9348a1c691c10271c9373bd31da67f

21. RStudio Team (2020) RStudio: Integrated Development for R. RStudio, PBC, Boston, MA URL http://www.rstudio.com/.

22. Carslaw, D.C. and K. Ropkins, (2012) openair — an R package for air quality data analysis. Environmental Modelling \& Software. Volume 27-28, pp. 52-61.

23. Carslaw, D.C. (2015) The openair manual — open-source tools for analysing air pollution data. Manual for version 1.1-4, King's College London.

24. Waddington, J. M., Morris, P. J., Kettridge, N., Granath, G., Thompson, D. K. and Moore, P. A. (2015) Hydrological feedbacks in northern peatlands, Ecohydrology., 8, pages 113-127, doi: 10.1002/ eco.1493

25. Sebestyen, S. D., Verry, E. S., \& Brooks, K. N. (2011) Hydrological responses to forest cover changes on uplands and peatlands. In Kolka, R. K., Sebestyen, S. D., Verry, E. S., \& Brooks, K. N. (Eds.), Peatland biogeochemistry and watershed hydrology at the Marcell Experimental Forest (pp. 433-458). Boca Raton, FL: CRC Press.

26. Sivakumar, B. (2000) Chaos theory in hydrology: Important issues and interpretations. Journal of Hydrology, 227(1), 1-20. https:/ / doi.org/10.1016/S0022-1694(99)00186-9

27. Bridgham, S. D., Pastor, J., Dewey, B., Weltzin, J. F., \& Updegraff, K. (2008) Rapid Carbon Response of Peatlands to Climate Change. Ecology, 89(11), 3041-3048. https:// doi.org/10.1890/08-0279.1

28. Moore, P. A., Pypker, T. G., \& Waddington, J. M. (2013). Effect of long-term water table manipulation on peatland evapotranspiration. Agricultural and Forest Meteorology, 178-179, 106-119.

29. Shi, X., Thornton, P. E., Ricciuto, D. M., Hanson, P. J., Mao, J., Sebestyen, S. D., Griffiths, N. A., \& Bisht, G. (2015) Representing northern peatland microtopography and hydrology within the Community Land Model. Biogeosciences, 12(21), 6463-6477. bttps://doi.org/10.5194/bg-12-6463-2015

30. Graham, J. D., Glenn, N. F., Spaete, L. P., \& Hanson, P. J. (2020) Characterizing peatland microtopography using gradient and microform-based approaches, Ecosystems. https:// doi.org/10.1007/s10021-020-00481-z.

31. Verry, E. S. (1984) Microtopography and water table fluctuation in a Sphagnum mire, Proceedings of the 7th International Peat Congress, Dublin, Ireland, edited, pp. 11-31, The Irish National Peat Committee / The International Peat Society.

32. Malhotra, A., Brice, D. J., Childs, J., Graham, J. D., Hobbie, E. A., Stel, H. V., Feron, S. C., Hanson, P. J., \& Iversen, C. M. (2020) Peatland warming strongly increases fine-root growth. Proceedings of the National Academy of Sciences. https:/ / doi.org/10.1073/pnas.2003361117

33. Jiang, J., Huang, Y., Ma, S., Stacy, M., Zheng, S., Ricciuto, D., Hanson, P., \& Luo, Y. (2018) Forecasting responses of a northern peatland carbon cycle to elevated $\mathrm{CO} 2$ and a gradient of experimental warming. Journal of Geophysical Research: Biogeosciences, 123(3), 1057-1071. https:// doi.org/10.1002/2017JG004040

34. Collins, M., Knutti, R., Arblaster, J., Dufresne, J-L., Fichefet, T., Friedlingstein, P., Gao, X., Gutowski, W.J., Johns, T., Krinner, G., Shongwe, M., Tebaldi, C., Weaver, A.J., Wehner, M. (2013) Long-term Climate Change: Projections, Commitments and Irreversibility. In: Climate Change 2013: The Physical Science Basis. Contribution of Working Group I to 
the Fifth Assessment Report of the Intergovernmental Panel on Climate Change [Stocker, T.F., D. Qin, G.-K. Plattner, M. Tignor, S.K. Allen, J. Boschung, A. Nauels, Y. Xia, V. Bex and P.M. Midgley (eds.)]. Cambridge University Press, Cambridge, United Kingdom and New York, NY, USA.

35. Ricciuto, D. M., Xu, X., Shi, X., Wang, Y., Song, X., Schadt, C. W., Hanson, P. J. (in press). An integrative model for soil biogeochemistry and methane processes: I. Model structure and sensitivity analysis. Journal of Geophysical Research, G, Biogeosciences.

36. Feng, X., Deventer, M. J., Lonchar, R., Ng, G. H. C., Sebestyen, S. D., Roman, D. T., Kolka, R. K. (2020) Climate sensitivity of peatland methane emissions mediated by seasonal hydrologic dynamics. Geophysical Research Letters, 47(17), e2020GL088875. https://doi.org/10.1029/2020g1088875

37. Parsekian, A. D., Slater, L., Ntarlagiannis, D., Nolan, J., Sebestyen, S. D., Kolka, R. K., \& Hanson, P. J. (2012) Uncertainty in peat volume and soil carbon estimated using ground-penetrating radar and probing, Soil Sci. Soc. Am. J., 76(5), 1911-1918. https:// doi.org/10.2136/sssaj2012.0040

38. Hill, B. H., Jicha, T. M., Lehto, L. L. P., Elonen, C. M., Sebestyen, S. D., \& Kolka, R. K. (2016) Comparisons of soil nitrogen mass balances for an ombrotrophic bog and a minerotrophic fen in northern Minnesota, Sc. Total Environ., 550, 880-892. bttps:// doi.org/10.1016/j.scitotenv.2016.01.178

39. Verry, E. S., \& Janssens, J. (2011) Geology, vegetation, and hydrology of the S2 bog at the MEF: 12,000 years in northern Minnesota, in Peatland biogeochemistry and watershed hydrology at the Marcell Experimental Forest, edited by Kolka, R. K., et al., pp. 93-134, CRC Press, Boca Raton, FL.

\section{ABOUT STUDENT AUTHOR}

Anna Stockstad graduated from the University of Minnesota in May 2020 with a Bachelor of Science in Forest and Natural Resource Management and minors in environmental science and wildlife biology. She is currently a Master of Science student in the Natural Resource Science and Management program at the University of Minnesota and researching forest soil operability and biogeochemistry.

\section{PRESS SUMMARY}

Changes in water tables in northern peatlands strongly influence the health and productivity of these ecosystems. Peatlands (bogs and fens) cover ten percent of the surface area in Minnesota, USA, and thus are a critical part of the landscape. Long-term data (1961 to 2019) from the Marcell Experimental Forest were used to analyze the trends in water tables in northern peatlands. Responses were not consistent across peatland type, and water table trends were different between bogs and fens as a whole. Even though precipitation has not significantly changed since 1961, water tables in peatlands at the Marcell Experimental Forest have varied through time. These results show that water table trends within peatlands, which provide crucial ecosystem services, are likely site-specific and variable. These findings highlight a need for site-specific management plans and long-term hydrological modelling. 